\title{
Legers forhold til flyktningpasienten
}

\begin{abstract}
Sammendrag
Bakgrunn. Flyktningpasientens komplekse problemer representerer en utfordring for første- og annenlinjetjenesten. Språkvansker og kulturforskjeller kan gjøre forståelse av symptomer og plager vanskelig. I denne undersøkelsen ønsker vi å se på hvordan leger oppfatter, forholder seg til og vurderer sin kompetanse i forhold til flyktningpasienten.
\end{abstract}

Materiale og metode. Hvert annet år mottar et representativt utvalg av norske yrkesaktive leger, det såkalte referansepanelet, spørreskjemaer som tar opp helsepolitiske og arbeidsrelaterte temaer. Vi inkluderte i 2006 11 spørsmål om legenes erfaringer med flyktninger og asylsøkere som pasienter.

Resultater. De fleste mente de hadde middels kompetanse i forhold til denne pasientgruppen. $28 \%$ av fastlegene vurderte sin kompetanse som lav. $29 \%$ av legene likte «under middels godt» eller «dårlig» å arbeide med denne pasientgruppen. $70 \%$ av fastlegene og $55 \%$ av psykiaterne mente det var vanskelig eller umulig å få kontakt med faglig ekspertise for å få råd og veiledning i forhold til denne pasientgruppen. $51 \%$ sa at de hadde dårlig erfaring med henvisning til psykiater eller psykiatrisk sykehusavdeling. Legene visste ofte ikke om pasienten hadde vært traumatisert.

Fortolkning. Fastlegene, som har hovedansvaret for denne pasientgruppen, opplever at rammevilkårene for behandling/rehabilitering er utilstrekkelig og at psykisk helsevern ikke yter tilstrekkelig hjelp.

\section{Sverre Varvin}

sverre.varvin@nkvts.unirand.no

Nasjonalt kompetansesenter om vold

og traumatisk stress

Kirkeveien 166

0407 Oslo

\section{Olaf Gjerløw Aasland}

Legeforeningens forskningsinstitutt og

Institutt for helseledelse og helseøkonomi Universitetet i Oslo
Flyktninger med posttraumatiske tilstander og andre problemer knyttet til forfølgelse, flukt og eksil utgjør en stadig større del av pasientpopulasjonen i helsevesenet. Disse pasientene har ofte somatiske eller psykiatriske symptomer med bakenforliggende komplekse og sammensatte problemer som utfordrer systemets evne til samarbeid og integrasjon av behandlings- og rehabiliteringstilbud. Det kan dreie seg om kompliserte psykiske og somatiske følgetilstander etter tortur og andre overgrep, ofte kompliserte tilpasningsproblemer med familiekonflikter, vansker med språkopplæring, tilpasning til arbeidslivet og generell tilpasning til det norske samfunnet. Mange har kompliserte tapsopplevelser (tap av nære personer, familiær forankring, muligheter for fremtidig utvikling m.m.). Behandlingsopplegg for denne gruppen krever derfor ofte integrerte tilbud med samarbeid mellom flere instanser som psykiatriske og somatiske helsetjenester og sosialtjeneste.

Etablering av en behandlingsallianse kan være krevende med traumatiserte pasienter, da overgrep kan svekke tillit til andre mennesker. Bruk av tolk er for mange leger uvant, noe som kan vanskeliggjøre etablering av en god allianse. For fastlegen kan råd og veiledning fra psykiatrien og eventuelt samarbeid om behandlingen ofte være nødvendig (1).

I en kartlegging av tilbudet til traumatiserte ofre for tortur, vold og andre overgrep samt ulykker og katastrofer, utført ved Nasjonalt kunnskapssenter om vold og traumatisk stress (NKVTS), fant man at behandlingsenheter og behandlere i mindre grad enn for andre voldsrammede kunne gi flyktninger og torturofre den behandlingen de ønsket. Bare vel 10\% av enhetene anga at de fikk gitt den behandling de selv anså som ønskelig til denne gruppen. I tillegg til manglende kapasitet og ressurser og dårlig oppfølging og samarbeid med andre instanser, var det særlig mangelfull kompetanse som ble angitt som årsak til denne forskjellen (2). Undersøkelsen viste også at mange flyktninger og torturofre blir avvist av psykiatrien.

I en kvalitativ undersøkelse av fastlegens forhold til flyktningpasienten fant man at fastlegens møte med flyktningpasienter kunne være preget av usikkerhet dersom flyktningstatus og flukterfaringer hadde relevans for pasientens helsestatus (3). Fastlegene var tilbakeholdne med å invitere til samtaler om traumatiske opplevelser knyttet til situasjonen i hjemlandet, flukten og eksiltilværelsen. De var opptatt av at annen kultur og ukjent språk vanskeliggjorde kommunikasjonen og kontakten mellom lege og pasient. De opplevde at spesialisthelsetjenesten var lite tilgjengelig både for pasientene og som veileder for fastlegen. De konkluderte med at «et mangelfullt tilbud i spesialisthelsetjenesten ser ut til å plassere fastlegen alene i behandlingen».

Selv om mange trenger integrerte behandlings- og/eller rehabiliteringsopplegg, kan pasienter med alvorlige posttraumatiske plager også hjelpes med relativt lavintensive behandlingsopplegg. Det ser imidlertid ut til å være mangel på kapasitet, kunnskap og samarbeidsmuligheter. Derfor ønsket vi å undersøke hvor ofte norske leger møter flyktningpasienter, hvordan de opplever slike møter i forhold til egen kompetanse, og hvordan de opplevde samarbeidet mellom primær- og spesialisthelsetjenesten på dette området.

\section{Materiale og metode}

Et representativt utvalg av norske yrkesaktive leger, det såkalte referansepanelet, får annethvert år spørreskjemaer som tar opp helsepolitiske og arbeidsrelaterte temaer samt spørsmål om aktuell stilling, jobbtilfredshet og generell tilfredshet. Spørsmålene er de samme hver gang. Referansepanelet startet med ca. 1200 leger i 1994 og ble utvidet til 1606 i 2000. I 2006 fikk 1400 av de opprinnelige 1606 spørreskjemaet (en del var blitt pensjonister i mellomtiden og var dermed ikke lenger med i panelet). 966 svarte (69\%), hvorav 227 var fastleger. I 2006 ble det stilt en del spørsmål om legenes erfaring med flyktninger og asylsøkere som pasienter. Siden slike spørsmål ikke var stilt tidligere, ble de utformet for anledningen av artikkelforfatterne (ramme 1).

Vi rapporterer resultatene i spørreunder-

\section{Hovedbudskap}

- Flyktningers helseplager er sammensatte, med både psykiske og somatiske komponenter, og disse pasientene trenger integrert innsats

- De fleste leger mente de hadde middels kompetanse i håndtering av pasientgruppen og $28 \%$ av fastlegene vurderte sin kompetanse som lav

- Psykisk helsevern yter ikke tilstrekkelig hjelp til denne pasientgruppen 
søkelsen utelukkende som frekvensfordelinger, der vi skiller mellom sykehusleger $(\mathrm{n}=510)$, privatpraktiserende spesialister $(\mathrm{n}=70)$, fastleger $(\mathrm{n}=227)$ og andre leger $(\mathrm{n}=153)$. Seks leger har ikke oppgitt aktuell arbeidssituasjon.

\section{Resultater}

$42 \%(396 / 943)$ av legene hadde hatt minst fem asylsøkere og 39\% (364/939) minst fem flyktninger til behandling siste år. $31 \%$ (295/938) hadde hatt både flyktninger og asylsøkere. Av disse hadde $29 \%$ (86/295) hatt flere enn 20 slike pasienter siste år. $\AA$ ha 20 pasienter eller mer var vanligst blant de privatpraktiserende spesialistene, med $28 \%$ (95\% KI 18-40), tett fulgt av fastlegene med $25 \%$ (95\% KI 19-31), og med sykehuslegene noe lavere på $15 \%$ (95\% KI 12-19) (fig 1).

I spesialisthelsetjenesten (sykehusleger og privatpraktiserende spesialister) anga $68 \%$ at konsultasjonene hovedsakelig gjaldt somatiske helseproblemer. $46 \%$ av sykehuslegene visste imidlertid ikke om pasientene hadde hatt traumatiske opplevelser i form av vold, krig, overgrep, tortur eller liknende. Blant fastlegene sa $58 \%$ at konsultasjonene dreide seg om både psykiske og somatiske plager (likelig fordelt), og $78 \%$ av dem som hadde erfaring med slike pasienter, visste om pasientene hadde vært utsatt for vold, krig, overgrep eller tortur. På spørsmål om hvordan legene vurderte sin kompetanse til å møte disse pasientene svarte de fleste at de syntes de hadde middels kompetanse (sykehusleger $57 \%$, privatpraktiserende spesialister $72 \%$, fastleger $54 \%$ ). Det var imidlertid en relativt høy andel av fastlegene (28\%) som svarte at de vurderte sin kompetanse som lav. $29 \%$ av legene likte «under middels godt» eller «dårlig» å arbeide med denne pasientgruppen.

$70 \%$ av fastlegene og $55 \%$ av psykiaterne svarte at det var vanskelig eller umulig å få kontakt med faglig ekspertise for å få råd og veiledning $i$ forhold til denne pasientgruppen. Tilsvarende tall for sykehusleger og privatpraktiserende spesialister var henholdsvis $41 \%$ og $28 \%$.

$48 \%$ av fastlegene henviser noen få og $26 \%$ en del av flyktningpasientene til psykiater eller psykiatrisk sykehusavdeling, og $51 \%$ sa at de hadde dårlig erfaring med dette. Generelt henvises disse pasientene lite videre. Aktuell og tilgjengelig kunnskap for leger om flyktning- og asylsøkerpasienter finnes bl.a. på hjemmesiden til Nasjonalt kunnskapssenter om vold og traumatisk stress (4) og i Norsk elektronisk legehåndbok (5), og disse to kildene var nevnt spesielt i spørreskjemaet. Vel 3\% benyttet veilederen fra Nasjonalt kunnskapssenter om vold og traumatisk stress, $4 \%$ benyttet Norsk elektronisk legehåndbok, $16 \%$ leste i tidsskrifter og $13 \%$ benyttet annet skriftlig materiale. Fastlegene benyttet alle fire kategorier mest.

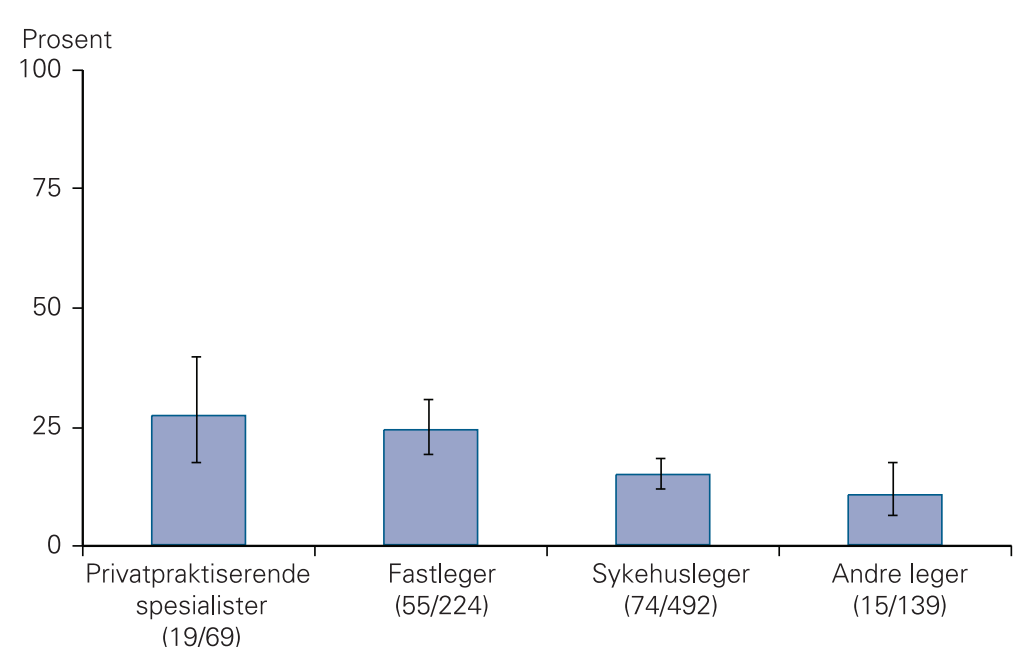

Figur 1 Andel leger som har hatt minst 20 asylsøker-og/eller flyktningpasienter siste år angitt i prosent med $95 \%$ konfidensintervall

\section{Diskusjon}

De fleste legene arbeider med flyktningpasientenes somatiske plager og vet ofte ikke om det dreier seg om traumatiserte pasienter eller ikke. Sannsynligvis er det mange leger som heller ikke spør om dette, kanskje av frykt for å bli involvert i mer enn det som blir presentert.
Fastlegene har naturlig nok hovedansvaret for å kjenne til helheten i flyktningpasientenes sammensatte psykiske, sosiale og somatiske problemer. Men bare ca. $20 \%$ av fastlegene mente at de hadde god kompetanse på området. Siden det både synes å være vanskelig å få råd og veiledning i dette arbeidet og vanskelig å få henvist

\section{Ramme 1}

Spørsmål om legers erfaringer med flyktninger og asylsøkere som pasienter, stilt i spørreundersøkelse i referansepanelet 2006

1. Omtrent hvor mange asylsøkere har du hatt som pasienter siste år?

2. Omtrent hvor mange flyktninger har du hatt som pasienter siste år?

- Svaralternativer: ingen, mindre enn 5, mellom 5 og 20, flere enn 20

3. Hva dreide konsultasjonene med flyktninger og asylsøkere seg hovedsakelig om?

- Svaralternativer: hovedsakelig somatiske sykdommer og plager, hovedsakelig psykiske sykdommer og plager, somatiske og psykiske plager omtrent likelig fordelt, annet

4. Har noen av disse pasientene hatt traumatiske opplevelser tidligere, for eksempel vold, krig, overgrep, tortur eller lignende?

- Svaralternativer: nei, vet ikke, ja ca. _ _ \% av dem

5. Hvordan vurderer du din egen kompetanse i forhold til å møte disse pasientene?

- Svaralternativer: ingen eller minimal, lav, middels, over middels, høy

6. Hvordan liker du å arbeide med disse pasientene? - Svaralternativer: dårlig, under middels godt, middels godt, godt, svært godt

7. Hvor lett eller vanskelig er det å få kontakt med faglig ekspertise for å få råd og veiledning i forhold til disse pasientene?

8. Hvor lett eller vanskelig er det å få henvist disse pasientene til spesialist?

- Svaralternativer: umulig, vanskelig, verken vanskelig eller lett, lett, svært lett

9. Hvor mange av disse pasientene henviste du til psykolog, psykiater eller psykiatrisk sykehusavdeling i løpet av det siste året?

- Svaralternativer: ingen, noen få, en del, de fleste, vet ikke

10. Hva er din erfaring med å henvise disse pasientene til psykiater eller psykiatrisk sykehusavdeling?

- Svaralternativer: hovedsakelig dårlig, under middels godt, middels godt, godt, svært godt, annet

11. Har du noen ganger benyttet følgende skriftlige materiale i forbindelse med arbeid med flyktninger og asylsøkere:

- Artikler om flyktninger på NEL (Norsk elektronisk legehåndbok)

- Veileder om flyktninghelse fra NKVTS (Nasjonalt kunnskapssenter om vold og traumatisk stress)

- Artikler om flyktninghelse i medisinske tidsskrifter

- Annet skriftlig materiale om flyktninghelse 
flyktningpasienter til spesialisttjenesten, inkludert psykiatrien, er det grunn til å tro at fastlegene ofte unnlater å «åpne opp» for dialoger om tidligere traumer og konsentrerer seg om det aktuelle symptomet. Mønsteret ser ut til å være at de fleste spesialister eller sykehus behandler det pasienten eventuelt er henvist for, mens fastlegene sannsynligvis har et mer omfattende og langvarig behandlingsansvar.

Spørreskjemaer med faste svarkategorier fanger bare opp en begrenset del av legenes hverdag med flyktningpasienter. Men vi kan likevel danne oss et generelt bilde som viser at disse pasientene sannsynligvis får den «symptomatiske» helsehjelpen de trenger, mens deres bakenforliggende lidelser forblir ubehandlet. Når vi vet at disse lidelsene kan og bør behandles tidlig, og ikke minst at ubehandlede traumatiske tilstander har tendens til å bli kroniske, ofte med selvdestruktiv atferd (sjeldnere utadrettet destruktiv atferd) (6), burde vi øke vår beredskap og kompetanse på dette feltet. Det er ikke så mye som skal til, først og fremst at leger flest gjør seg bedre kjent med hvor de kan finne forskningsbasert informasjon om håndtering av flyktningpasienter. Dessuten hadde det nok vært en fordel at denne pasientgruppen ble betraktet som en spesiell risikogruppe, f.eks. i forbindelse med henvisning til psykiatrien, slik at henvisende lege opplever at det er mulig å få hjelp av andre med høyere kompetanse.

Det er neppe tvil om at helsevesenet vil tjene på å ruste opp behandlingstilbudet for denne gruppen pasienter. Det finnes imidlertid få behandlingsundersøkelser for denne gruppen og ingen studier der man har undersøkt virkningen av integrerte behandlingstilbud. Det er heller ingen kontrollerte psykiatriske behandlingsstudier. Det er imidlertid noen studier som viser at behandling kan hjelpe (7-9), og det er igangsatt undersøkelser der man skal se på hvordan behandlings- og rehabiliteringstiltak fungerer i en distriktspsykiatrisk setting (10).

Det er ofte rapportert usikkerhet omkring og tilbakeholdenhet med å gå inn på traumatiske forhold både i primærhelsetjenesten og i psykiatrien. Denne tilbakeholdenheten kan være ubegrunnet. En etterundersøkelse av 839 pasienter behandlet ved et distriktspsykiatrisk senter i Sverige (11) der ingen hadde fått diagnosen posttraumatisk stressforstyrrelse, viste 3-4 år senere høy frekvens (77\%) av rapporterte traumatiske opplevelser og sannsynlig posttraumatisk stressforstyrrelse på behandlingstidspunktet (29-69\% fordelt på forskjellige etniske grupper). Denne lidelsen var assosiert med multiple traumer hos pasient og/eller pårørende. Pasienter med diagnosen hadde signifikant dårligere forløp enn de uten diagnosen. Der traumer likevel hadde vært fokus i behandlingen, var prognosen bedre.

Tilbakeholdenhet kan også være begrun- net i tidsfaktoren, men selv lang tid etter traumatisering kan behandling av posttraumatiske reaksjoner være mulig. Strous og medarbeidere fant $\mathrm{i}$ en unders $ø$ kelse (med videovitnesbyrdmetoden) av holocaustoverlevere $\mathrm{i}$ Israel at behandling mange år etterpå ga en signifikant reduksjon av forstyrrelser i fungering og reduksjon av intensitet og alvorlighet av posttraumatiske symptomer (12)

Mange flyktningpasienter har opplevd tap og brudd i sitt liv og er av den grunn meget sårbare for brudd i behandlingskontakter. Dette skjer dessverre ofte i psykiatrien, der det kan være stor utskiftning av personell f.eks. ved distriktspsykiatriske sentre. Mange vil av flere grunner trenge langvarig stabil behandling. Fastlegen kan ofte tilby dette, det kan også praktiserende psykiatere og psykologer. Uansett er koordinering og integrering av tiltak viktig. Det er tankevekkende at man i hovedstadsområdet $\mathrm{i}$ Norge, der de fleste flyktninger bor, ikke har etablert en tredjelinjetjeneste der de alvorligst rammede kan behandles, der systematisk forskning kan gjøres og der kompetansen kan vedlikeholdes og utvikles.

Oppgitte interessekonflikter: Ingen

\section{Litteratur}

Varvin S. Flyktningpasienten. Oslo: Universitetsforlaget, 2008

2. Hjemdal $\mathrm{O}$. Kartlegging av tilbudet til traumatiserte ofre for vold, overgrep, ulykker og katastrofer, flyktninger og torturofre. Oslo: Nasjonalt kunnskapssenter om vold og traumatisk stress, kunnsk

\section{6}

3. Grut L, Tingvold L, Hauff E. Fastlegens møte med flyktninger. Tidsskr Nor Lægeforen 2006; 126 : $1318-20$

4. Dahl S, Sveaass N, Varvin S, red. Psykiatrisk og psykososialt arbeid med flyktninger - veileder. Oslo: Nasjonalt kunnskapssenter om vold og traumatisk stress, 2006

5. Varvin S. Veileder for undersøkelse av torturskadde og andre alvorlig traumatiserte. Oslo: Menneskerettsutvalget, Den norske lægeforening 2004

6. Goenjian AK, Steinberg AM, Najarian LM et al. Prospective study of posttraumatic stress, anxiety, and depressive reactions after earthquake and political violence. Am J Psychiatry 2000; 157. 911-6.

Boehnlein J, Kinzie JD, Sekiya U et al. A ten-year treatment outcome study of traumatized Cambodian refugees. J Nerv Ment Dis 2004; 192: 658-63.

8. Berliner P. Mikkelsen EM, Bovbjerg A et al. Psychotherapy treatment of torture survivors - brief therapy for asylum seeking traumatised refugees at the Danish Red Cross. International Journal of Psychosocial Rehabilitation 2004; 8: 85-96.

Varvin S. Mental survival strategies after extreme traumatisation. København: Multivers, 2003

10. Varvin S, Opaas M. Behandling og rehabilitering av alvorlig traumatiserte flyktninger. Forskningspro sjekt. Oslo: Nasjonalt kunnskapsseenter om vold og traumatisk stress, 2006

11. Al-Saffar S. Trauma, ethnicity and posttraumatic stress disorder in outpatient psychiatry. Doktoravhandling. Stockholm: Stockholms universitet, 2003

12. Strous RD, Weiss M, Felsen I et al. Video testimony of long-term hospitalized psychiatrically ill Holocaust survivors. Am J Psychiatry 2005; 162 : 2288-94
Verdens helse

\section{Skabbehandling i Senegal}

Topisk behandling for skabb med benzylbenzoat fungerte bedre enn peroral ivermectin. Det er konklusjonen av en åpen, randomisert studie fra en dermatologiklinikk i Dakar, Senegal (1).

Det er rundt 300 millioner tilfeller av skabbinfeksjon i verden hvert år. Skabb er et stort problem i utviklingsland, fordi det forekommer så hyppig og komplikasjoner er vanlig. Skabb ser ut til å forekomme oftere hos barn, som også har større risiko for superinfeksjon med streptokokker.

Pasienter i alderen 5-65 år med skabb som kom til en hudavdeling i Dakar ble inkludert. Disse ble randomisert til enten å få én behandling i 24 timer med 12,5\% benzylbenzoat (BB1, $\mathrm{n}=68$ ), to behandlinger over 24 timer med $12,5 \%$ benzylbenzoat (BB2, $n=48$ ) eller oral ivermectin $150-200 \mu \mathrm{g} / \mathrm{kg}$ (IV, $\mathrm{n}=65$ ).

Etter 14 dager var 33 pasienter $(68,8 \%)$ helbredet i BB2-gruppen sammenliknet med $37(54,4 \%)$ i BB1-gruppen og 16 $(24,6 \%)$ i IV-gruppen. Bakteriell superinfeksjon var mer vanlig i IV-gruppen sammenliknet med BB1-og BB2-gruppen samlet ( $28 \%$ versus $7,8 \%$ ). Etter 28 dager var $46(95,8 \%)$ i BB2-gruppen helbredet sammenliknet med $52(76,5 \%)$ i BB1gruppen og $28(43,1 \%)$ i IV-gruppen.

Over $51 \%$ hadde mer enn fem familiemedlemmer som også trengte behandling. Ettersom flere familiemedlemmer ofte er infisert, er økonomiske hensyn viktig med tanke på valg av behandling i utviklingsland som Senegal. Siden forskjellen i effekt mellom én og to behandlinger med benzylbenzoat var relativt moderat, anbefaler forfatterne bruk av én behandling i første omgang som standard ved vanlig skabb. En andre behandling kan gjøres om dette ikke har noen effekt. Kostnaden for én behandling med generisk benzylbenzoat er for tiden ca. 0,1 euro.

\section{Oda Riska}

oriska@hotmail.com

Tidsskriftet

\section{Litteratur}

1. Ly F, Caumes E, Ndaw CAT et al. Ivermectin versus benzyl benzoate applied once or twice to treat human scabies in Dakar, Senegal: a randomized controlled trial. Bull World Health Organ 2009: 87: 424-30. DOI: 10.2471/ BLT.08.052308. 